\title{
5. LIPID ANALYSES OF SEDIMENTS FROM SITE 364 IN THE ANGOLA BASIN, DSDP LEG $40^{1}$
}

\author{
Bernd R.T. Simoneit, Institute of Geophysics and Planetary Physics, \\ University of California, Los Angeles, California
}

\begin{abstract}
The lipids extracted from samples in the Angola Basin (Site 364) were examined for terrigenous components. A Pleistocene sample contained $n$-alkanes and $n$-fatty acids of both autochthonous origin and terrigenous influx from the Zaire River. The paleoenvironmental conditions were oxic. A Cretaceous sample, representative of the Aptian sapropelic sequence in the basin, contained lipids derived from both marine and terrigenous sources and was deposited under anoxic conditions. Diterpenoids and carbon isotope ratios were used as the primary indicators for terrigenous lipids.
\end{abstract}

\section{INTRODUCTION}

Samples from various DSDP drill sites have been examined for their content of terrigenous lipids (e.g., Simoneit, 1975; Aizenshtat et al., 1973). The Angola Basin has been described as a sink for terrigenous influx during various times of its evolution (Bolli et al., 1975). Thus, it was of interest to determine if the analyses of the lipid matter could distinguish autochthonous marine from allochthonous terrigenous lipids and if some inferences about the paleoenvironmental conditions of sedimentation could be proposed.

The samples examined here were derived from Site 364 , drilled on Leg 40 , located in the continental margin of the eastern Angola Basin $\left(11^{\circ} 34.4^{\prime} \mathrm{S}\right.$, $11^{\circ} 58.3^{\prime} \mathrm{E}$; water depth: $2448 \mathrm{~m}$ ).

\section{EXPERIMENTAL}

The core samples were freeze-dried and then extracted with toluene and methanol (4:1) using ultrasonication. The extracts for each sample were concentrated on a rotary evaporator and subjected to gas chromatographic analysis (GC). The extracts were then treated with diazomethane in ether and subjected to silica gel thin-layer chromatography (TLC) using methylene chloride as eluent. The bands corresponding to hydrocarbons and esters were scraped off the TLC plate after development with iodine vapor, and eluted with ether or ethyl acetate. These fractions were subjected to GC and GC/MS analyses.

The GC analyses were carried out on a HewlettPackard Model 5830 gas chromatograph using a $16 \mathrm{~m}$ $\times 0.75 \mathrm{~mm}$ stainless steel SCOT column coated with OV-101, programmed from $110-280^{\circ} \mathrm{C}$ at $4^{\circ} \mathrm{C}$ per minute using $\mathrm{He}$ carrier gas at a flow rate of $3 \mathrm{ml} / \mathrm{min}$.

\footnotetext{
'Contribution No. 1595: Institute of Geophysics and Planetary Physics, University of California at Los Angeles, Los Angeles, California.
}

The GC/MS analyses were carried out on a DuPont Model 21-492-1 mass spectrometer interfaced directly with a Varian Aerograph Model 204 gas chromatograph equipped with a $10 \mathrm{~m} \times 0.75 \mathrm{~mm}$ glass column which was packed with Gaschrom Q (80-100 mesh) coated with $1 \%$ OV-1.

The mass spectrometric data were acquired and processed using a DuPont Model 21-094 data system.

The stable carbon isotope analyses were carried out by the methodology described in Kaplan et al., 1970 versus the standard Chicago PDB.

The porphyrin spectra were obtained on bands separated by the TLC method of Didyk (1975) using UV-visible spectrophotometry.

\section{RESULTS AND DISCUSSION}

The sample descriptions, carbon analyses, and lipid yields are listed in Table 1.

The shallow sample (Section 364-1-2) from the Pleistocene consists of calcareous mud and clay, largely supplied by the Zäire River (Bolli et al., 1975). The organic carbon content is $1.3 \%$ and the lipid yield was relatively low. The distribution diagrams for the $n$ alkanes and $n$-fatty acids are shown in Figure 1 . The $n$ alkanes exhibit a bimodal distribution, with maxima at $n-\mathrm{C}_{17}$ and $n-\mathrm{C}_{23}$ and $\mathrm{CPI}=1.2$. The maximum in the region $n-\mathrm{C}_{27}$ to $n-\mathrm{C}_{31}$ usually associated with higher plant waxes (Simoneit, 1975; in press) is not very predominant. Also, the pristane to phytane ratio $(\mathrm{Pr} / \mathrm{Ph})$ is 1.5. This indicates that oxic environmental conditions probably prevailed during sedimentation (Didyk et al., in press) and some of the lipids were metabolized by microbiota. Such a bimodal distribution has been found for microbially altered algal residues (Johnson and Calder, 1973; Hatcher et al., in press). The $n$-fatty acids also exhibited a bimodal distribution, with maxima at $n-\mathrm{C}_{16}$ and $n-\mathrm{C}_{26}$ and CPI $=7.0$. The origin of these acids appears to be autochthonous ( $n-\mathrm{C}_{16}$ maximum) and terrigenous ( $n$ - 
TABLE 1

Sample Descriptions, Carbon Analyses, and Extract Yields for the Core Sections Examined

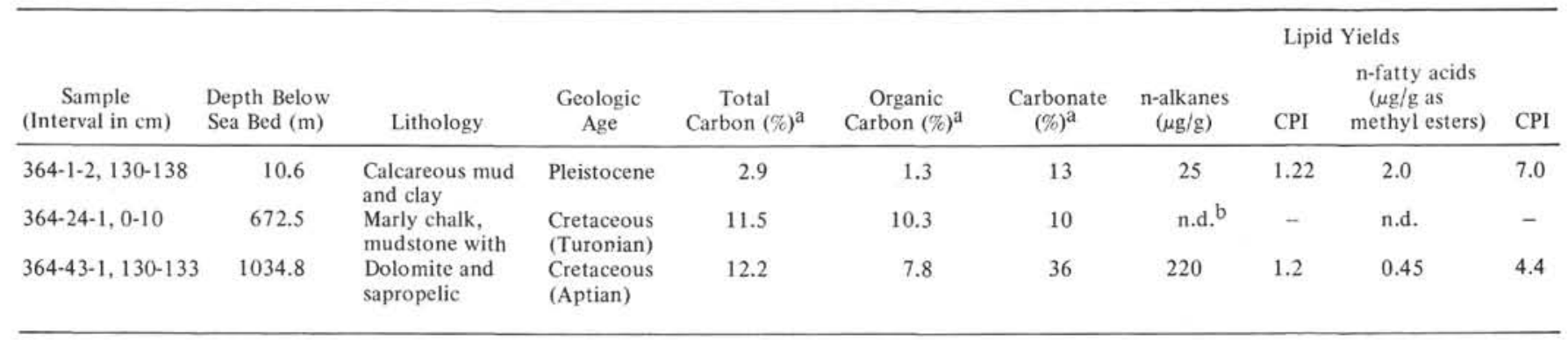

${ }^{a}$ Data supplied by G. Bode, Deep Sea Drilling Project, Scripps Institution of Oceanography, University of California at San Diego.

$\mathrm{b}_{\mathrm{n} . \mathrm{d} .}=$ not determined.

$\mathrm{C}_{26}$ maximum) (Hitchcock and Nicholls, 1971; Simoneit, 1975). Dehydroabietic acid (Structure I) is present in this fraction. This compound appears to be an exclusively terrigenous marker of higher plant diterpenoids (Simoneit, in press). Minor amounts of triterpenoids were detected. The major components consisted of probably a norhopane (Structure II) (molecular ion at m/e 398, loss of $\mathrm{CH}_{3}^{\circ}$ to m/e 383, base peak at $\mathrm{m} / \mathrm{e} 191$ and intense peak at $\mathrm{m} / \mathrm{e} 177$ ), and a hopane (Structure III) (molecular ion at $\mathrm{m} / \mathrm{e} \mathrm{412}$, loss of $\mathrm{CH}_{3}$ to $\mathrm{m} / \mathrm{e} 397$, loss of $\mathrm{C}_{3} \mathrm{H} ;$ to $\mathrm{m} / \mathrm{e} 369$ and base peak at $\mathrm{m} / \mathrm{e}$ 191). The minor components consist of unresolved isomers, probably of the hopane and/or moretane series. Traces of sterenes are present (based on peaks in the m/e 215 mass chromatogram of the GC/MS data), but no steranes, perylene, or $C_{32}$ triterpenoid acid were detected.

The deep sample (364-43-1) from the Aptian consists of black sapropelic mudstone and about $40 \%$ carbonate (Bolli et al., 1975). The organic carbon content is 7.8\% and the lipid yield was high, consisting mainly of polar material. The $n$-alkanes exhibited a trimodal distribution (cf. Figure $1 \mathrm{~b}$ ), with maxima at $n-\mathrm{C}_{17}$ (possible marine origin), $n-\mathrm{C}_{22}$ (possible altered lipid residue), and $n-\mathrm{C}_{29}$ (terrigenous plant wax). The overall CPI is 1.2 and the $\mathrm{Pr} / \mathrm{Ph}$ is 0.6 . The $n$-fatty acids exhibit a bimodal distribution (cf. Figure 1d), with maxima at $n$ $\mathrm{C}_{16}$ (possible marine origin) and $n-\mathrm{C}_{22}$ (possible terrigenous origin), and an overall CPI of 4.4. Phytanic and pristanic acids are present in significant amounts and have a ratio $(\mathrm{Pr} / \mathrm{Ph})$ of 0.7 , also less than 1.0 as was the case for the hydrocarbons. Dehydroabietic acid (Structure I) was detected and a minor amount of retene (Structure IV) is also present. Large amounts of aromatic hydrocarbons were found in the ester fraction. The major homologs are $\mathrm{C}_{14} \mathrm{H}_{10}$ (either anthracene or phenanthrene), $\mathrm{C}_{15} \mathrm{H}_{12}, \mathrm{C}_{16} \mathrm{H}_{14}, \mathrm{C}_{13} \mathrm{H}_{16}$, $\mathrm{C}_{14} \mathrm{H}_{18}$, and $\mathrm{C}_{15} \mathrm{H}_{20}$. Perylene was not detected in this sample.

The porphyrin content of this sample is significant and consisted mainly of about $30 \mathrm{ppm}$ (based on the extract) vanadyl-DPEP and VO-deoxophylloerythrin and about $35 \mathrm{ppm}$ nickel-deoxophylloerythrin. The presence of a large porphyrin component and an excess of the $\mathrm{C}_{20}$ isoprenoid skeleton over the $\mathrm{C}_{19}$ homolog indicate that the paleoenvironmental conditions in the Angola Basin were anoxic both in the water column and sediment (Didyk et al., in press). These conditions are corroborated by the preliminary core description (Bolli et al., 1975; Chapter 4, this volume). The presence of terrigenous markers in the lipids indicates an allochthonous contribution of lipid material to the basin. Some coalified plant debris was observed in the Aptian samples (Bolli et al., 1975). The analyses of the stable carbon isotopes further support a terrigenous input of organic matter to the basin. The data for Section 364-43-1 are: total extract $\delta^{13} \mathrm{C}=-26.5^{\circ} / 00$ and kerogen (carbonate-free, extracted residue) $\delta^{13} \mathrm{C}=$ $27.0^{\circ} \%$. These values are typical of land plants and also fall in the range of Cretaceous petroleums as well as the mean of petroleums in general (Degens, 1969). Marine organic matter exhibits more scatter in the general range of $\delta^{13} \mathrm{C}=-12$ to $-23 \%$ (Degens, 1969).

The lipid analyses for Section 364-24-1 have not been completed. Contamination from various plasticizers is minor and consists primarily of butyl and octyl phthalates, and dibutyl esters of dicarboxylic acids from the core tubes (Simoneit, 1975).

\section{CONCLUSIONS}

The lipids of the Pleistocene sample from Site 364 consist of marine and superimposed terrigenous components, with some of the homologs apparently microbially altered. The terrigenous lipid markers were probably brought to the basin by the Zäire River and deposited under oxic paleoenvironmental conditions.

The lipids of the Aptian sapropelic mudstone from Site 364 consist also of marine and superimposed terrigenous components, with some of the homologs apparently altered microbially. The paleoenvironmental conditions were anoxic both in the water column and sediment, as inferred from the high content of porphyrin pigments and low $\mathrm{Pr} / \mathrm{Ph}$. The presence of terrigenous lipid markers indicates an allochthonous contribution of lipids to the basin. The analyses of the stable carbon isotopes further support this thesis, which is corroborated by the presence of plant debris as reported in the core descriptions (see Chapter 4 , this volume).

\section{ACKNOWLEDGMENTS}

I thank the National Science Foundation for making the core samples available, R.P. Philp and S.C. Brown for GC/MS data, D. Winter for stable isotope analyses, and D. 

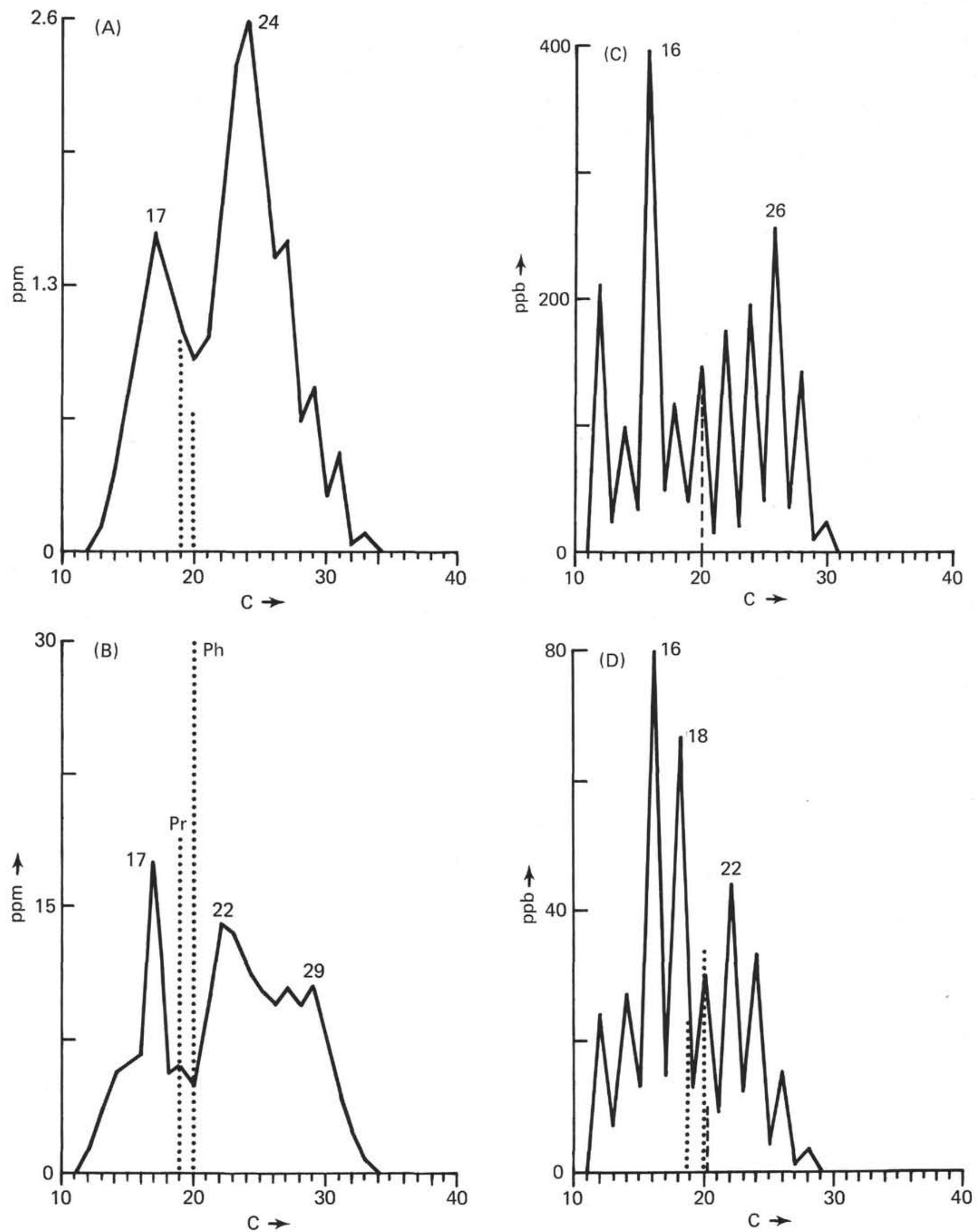

Figure 1. Distribution diagrams for the n-alkanes and n-fatty acids (..... isoprenoids; - . . - dehydroabietic acid). n-alkanes: (A) Sample 364-1-2, 130-138 cm; (B) Sample 364-43-1, 130-133 cm. n-fatty acids: (C) Sample 364-1-2, 130-138 cm; (D) Sample 346-43-1, 130-133 cm. 
Kosiur for porphyrin analyses. Partial financial assistance from the University of Alaska (NOAA Subcontract No. F01770) is gratefully acknowledged.

\section{REFERENCES}

Aizenshtat, Z., Baedecker, M.J., and Kaplan, I.R., 1973. Distribution and diagenesis of organic compounds in JOIDES sediment from Gulf of Mexico and western Atlantic: Geochim. Cosmochim. Acta, v. 37, p. 18811898.

Bolli, M.H., Ryan, W.B.F., McKnight, B.K., Kagami, H., Melguen, M., Siesser, W.G., Natland, J., Longoria, J.F., Proto-Decima, F., Foresman, J.B., and Hottman, W.E., 1975. Basins and margins of the eastern South Atlantic: Geotimes, v. 20, p. 22-24.

Degens, E.T., 1969. Biogeochemistry of stable carbon isotopes. In Eglinton, G. and Murphy, M.T.J. (Eds.), Organic geochemistry, methods and results: Berlin (Springer-Verlag), p. 304-329.

Didyk, B.M., 1975. The geochemistry of petroporphyrins: Ph.D. Thesis, University of Bristol, England.
Didyk, B.M., Simoneit, B.R.T., and Eglinton, G., in press. Geochemical indicators of paleoenvironmental conditions of sedimentation: Nature.

Hatcher, P.G., Gerchakov, S.M., Mackenzie, F.T., Neumann, A.C., Segar, D.A., Simoneit, B.R.T., and Thorstenson, D.C., in press. Mangrove Lake, Bermuda-Diagenesis in a sapropelic environment: Geochim. Cosmochim. Acta.

Hitchcock, C. and Nicholls, B.W., 1971. Plant lipid biochemistry: London (Academic Press).

Johnson, R.W. and Calder, J.W., 1973. Early diagenesis of fatty acids and hydrocarbons in a salt marsh environment: Geochem. Cosmochim. Acta, v. 37, p. 1943-1955.

Kaplan, I.R., Smith, J.W., and Ruth, E., 1970. Carbon and sulfur concentration and isotopic composition in Apollo 11 lunar samples: Apollo 11 Lun. Sci. Conf. Proc.-Geochim. Cosmochim. Acta, Suppl. 1, v. 2, New York (Pergamon) p. 1317-1329.

Simoneit, B.R.T., 1975. Sources of organic matter in oceanic sediments: Ph.D. Thesis, University of Bristol, England. , in press. The Black Sea, a sink for terrigenous lipids: Deep-Sea Res.

1977. Diterpenoidal compounds and other lipids in deep-sea sediments and their geochemical use as terrigenous markers: Geochim. Cosmochim. Acta. v. 41, p. 463-476.

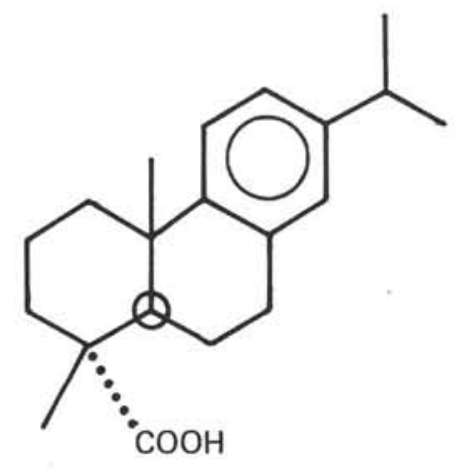

I $\mathrm{C}_{20} \mathrm{H}_{28} \mathrm{O}_{2}$<smiles>CC[C@H]1CC[C@@]2(C)C1CC[C@]1(C)C2CCC2C3(C)CCCC(C)(C)C3CCC21C</smiles>

II $\mathrm{C}_{29} \mathrm{H}_{50}$<smiles>CC(C)[C@H]1CC[C@@]2(C)C3CCC4C5(C)CCCC(C)(C)C5CCC4(C)[C@@]3(C)CC[C@]12C</smiles>

III $\mathrm{C}_{30} \mathrm{H}_{52}$<smiles>Cc1cccc2c1ccc1cc(C(C)C)ccc12</smiles>

IV $\mathrm{C}_{18} \mathrm{H}_{18}$ 